\title{
The Chatanika and Sondrestrom Radars - a brief history
}

\author{
M. A. McCready and C. J. Heinselman \\ The Center for Geospace Studies, SRI International, Menlo Park, California, USA \\ Correspondence to: M. A. McCready (mary.mccready@ sri.com) \\ and C. J. Heinselman (craig.heinselman@ sri.com)
}

Received: 15 November 2012 - Accepted: 24 January 2013 - Published: 21 February 2013

\begin{abstract}
The Sondrestrom upper atmospheric research facility, located just north of the Arctic Circle near the west coast of Greenland, will soon celebrate $30 \mathrm{yr}$ of operations. The centerpiece of the facility, an incoherent scatter radar, has collected $46000 \mathrm{~h}$ of data on the ionospheric state parameters. This instrument was designed and built to measure the effects of nuclear bombs on radio wave propagation in the South Pacific, but instead was deployed to Alaska to study the effects of auroral structuring on the ionosphere, and was later moved to Greenland to explore the auroral cusp and the dynamics of the polar cap boundary. This is the story of the birth and genesis of the instrument, its travels, and the evolution of its facility.
\end{abstract}

\section{The original plan - defense related research}

In the early 1960s, in advance of the US-USSR nuclear test ban treaty, the US government began preparing for aboveground nuclear tests over the South Pacific Ocean. Of particular concern were the global effects of high altitude (above $50 \mathrm{~km}$ ) nuclear detonations on long-range communications. Stanford Research Institute (which later became SRI International, a not-for-profit research organization) was funded by the US Department of Defense to study the effects of these detonations on radio wave propagation. In 1962, SRI fielded a multi-frequency $(400,800,1200 \mathrm{MHz})$ radar in the South Pacific on Johnston Island to study those effects on defense radar systems. Although those radars successfully collected unique and useful data on "effects" produced by the high altitude detonations, they could not obtain fundamental information on "causes" - the underlying physics that led to the observed effects.

Shortly after the conclusion of the tests, SRI realized that the new incoherent scatter radar (ISR) technique, which had been recently postulated and demonstrated, would get at the fundamental data needed to understand the underlying ionospheric physics associated with high altitude detonations. If the US were to ever repeat the high altitude nuclear tests, an ISR (with the capability of measuring plasma densities, temperatures, and motions) would be a much better diagnostic of the fundamental processes that produced the observed radar effects. With that in mind, the US Government funded SRI to design and build a transportable incoherent scatter radar. Thus, if nuclear tests were resumed again, a fully capable diagnostic radar would be available to move to the test region and observe the effects. The ISR that was built at Stanford, California, for this readiness program ultimately was moved to Chatanika, Alaska, and then to Sondrestrom, Greenland.

SRI first built and tested that ISR, shown in Fig. 1, on Stanford University's campus in Palo Alto, California, where SRI's engineers and scientists could easily develop and practice the use of such a radar together with data processing and analysis techniques. After some months of operation, it became apparent that performing measurements in a relatively benign mid-latitude environment was only useful to a certain extent. To prepare for operations in the much more dynamic, nuclear, disturbed environment would require moving the radar to an ionospheric environment that in many important ways simulated the nuclear environment.

\section{The first move - to the auroral zone}

SRI scientists suggested that the structuring of the ionospheric plasma by the aurora might affect radio wave propagation in much the same manner as a high altitude nuclear detonation and proposed moving the system from California to Chatanika, Alaska, 30 miles north of Fairbanks. The Department of Defense agreed and funded the move and 


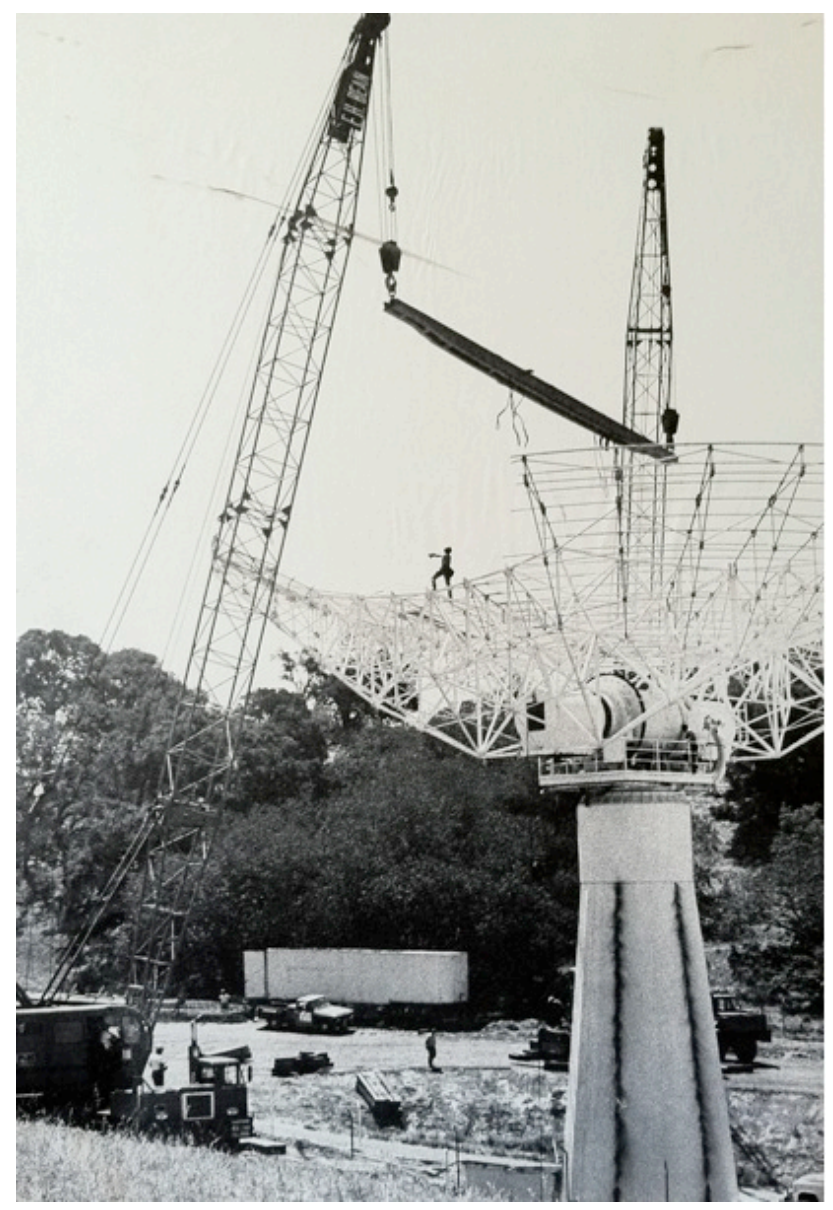

Figure 1. The $27 \mathrm{~m}$ ISR antenna at Stanford University, California.

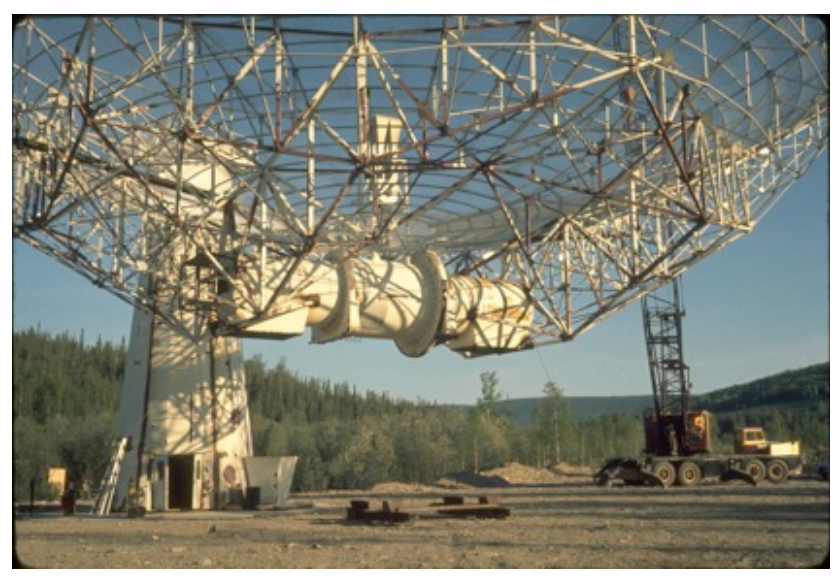

Figure 2. The assembly of the ISR in Chatanika, Alaska, in 1971.

initial operating costs. This placed the radar, shown during construction in Alaska in Fig. 2, under the nighttime section of the average auroral oval, where auroral ionospheric disturbances could be observed frequently (Leadabrand et al., 1972; Baron, 1977). The Chatanika Radar, with 3 MW

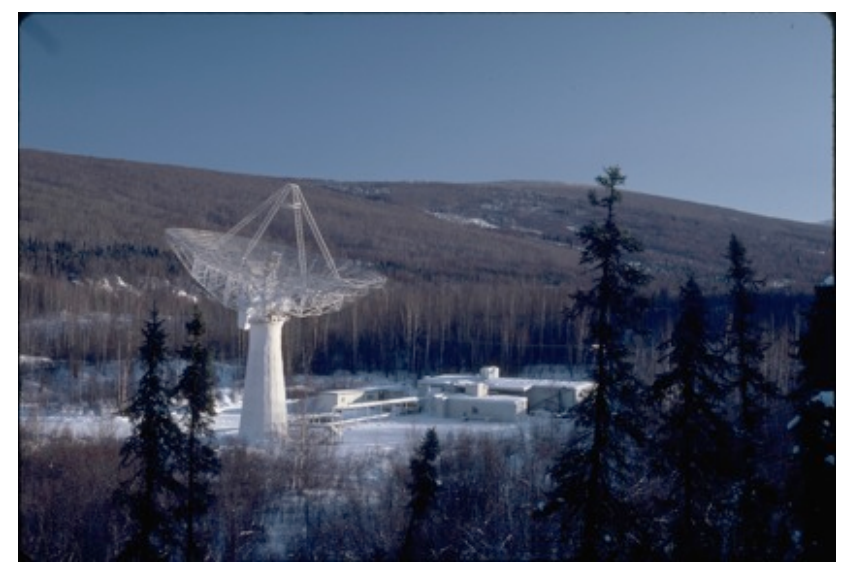

Figure 3. The Chatanika ISR, November 1981. Photo by C. Heinselman.

of power and a $27 \mathrm{~m}$ fully steerable dish antenna, was operated in Alaska from November 1971 to March 1982. The system recorded an average of $100 \mathrm{~h}$ of data monthly. Many radar experiments supported scientific sounding rockets that were launched from the nearby Poker Flat Research Range. The ISR facility provided complementary data to that collected by the rockets, and often helped determine the existence (or not) of desirable ionospheric conditions for launch. The radar also operated in concert with other ISRs worldwide for coordinated measurements of at least 24-h duration on a monthly basis.

Because the initial radar operations in Alaska produced significant new information on the auroral ionosphere, many scientists from across the US became interested in using it for their own research. Concurrently, the probability of further high altitude nuclear tests diminished and the US Department of Defense interest in the facility declined. Due to the growing purely scientific interest, the US National Science Foundation (NSF) increased its involvement in the project until, eventually, the radar operations were fully funded by the NSF. During its time in Chatanika, the radar also provided support for virtually all of the sounding rockets launched from the nearby Poker Flat Research Range, providing contextual information and, in many cases, helping to determine the existence of launch criteria. The facility, shown in Fig. 3, also supported a small number of optical instruments.

During the radar's time in Alaska, six European countries (Norway, Sweden, Finland, England, France and Germany) formed a consortium to design and build a three-dish incoherent scatter radar system in Scandinavia called the EISCAT (European Incoherent SCATter) Radar - a tristatic system in which one site transmits and all three receive. This technique of measuring the ion motion from three points removes the spatial/temporal ambiguity inherent in a monostatic (one-dish) system. The placement of the three dishes in northern Norway, Sweden and Finland also put the EISCAT radars under the nighttime auroral oval, in a very similar 
geomagnetic location as the Chatanika Radar. EISCAT also included a large mono-static radar which could make measurements to altitudes well over $1000 \mathrm{~km}$, but with limited antenna pointing capabilities. In order to help train EISCAT scientists before their own system became operational, many of the European members of EISCAT sent their scientists to Chatanika and to SRI in California to become familiar with the ISR technique. SRI provided training that enabled the EISCAT scientists to design and perform experiments at Chatanika.

As we approached almost a solar-cycle of measurements from Chatanika, SRI and the scientific community felt that many of the questions regarding auroral zone physics and aeronomy had been addressed, and that the remaining questions would be well addressed by the upcoming EISCAT Radars. Some of the groundbreaking work done with the Chatanika ISR is listed here, with representative references.

- Measurements of aurorally produced D- and E-regions (Hunsucker et al., 1972).

- Joule heating effects (Bates, 1973; Banks et al., 1981).

- Atmospheric gravity waves (Hunsucker, 1977).

- Substorm dynamics (Watkins and Belon, 1978).

- Electric field variations in and near auroral arcs (de la Beaujardière and Vondrak, 1982).

- Plasma convection (Foster et al., 1981).

- Effects of energy inputs on ion composition and the transition region (Kelly and Wickwar, 1981).

- Dynamics of the Harang Discontinuity (Kamide and Vickrey, 1983).

- Thermospheric neutral winds in the auroral zone (Wickwar et al., 1984).

- Determining the source of F-region density enhancements (Robinson et al., 1985).

- Ionospheric conductances (Robinson et al., 1987).

However, measurements from Chatanika during magnetic storms (when the auroral oval was expanded) had revealed new phenomena in the region poleward of the auroral oval, particularly near the boundary of the auroral oval and the polar cap. In addition, satellite measurements were showing perplexing ionospheric-magnetospheric interactions in the region of the noontime auroral oval (also called the cusp or cleft region). Because of community interest and support, in 1979 the NSF directed SRI to perform a study to examine the feasibility of moving the Chatanika Radar to a location that would enable routine measurements of the noontime auroral oval and of the boundary between the nighttime auroral oval and the polar cap. Such a move was practical only because the radar had, from the start, been designed to be transportable.

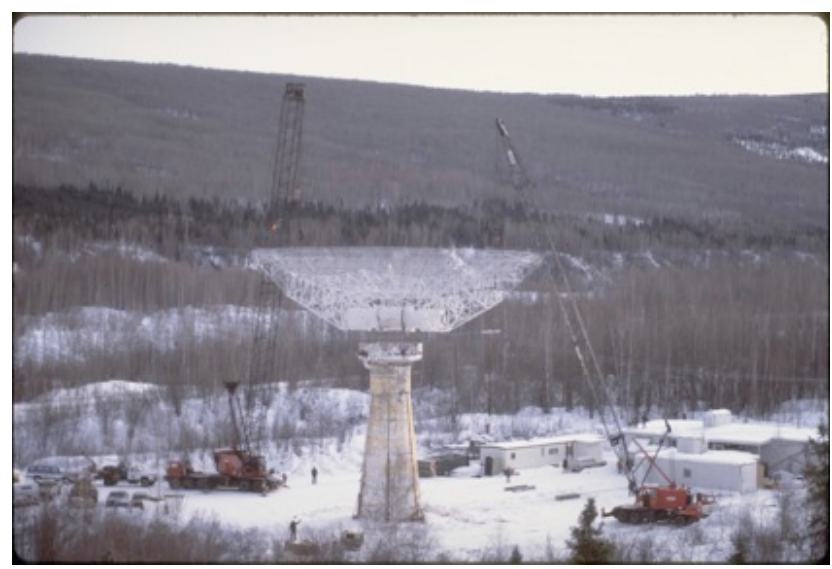

Figure 4. The removal of the reflector and torque tube from the gun mount, preparatory for shipping the system to Greenland. Photo by C. Heinselman.

\section{The second move - to the cusp}

During the feasibility study, siting criteria were established based on both scientific and logistical considerations. Only sites in northern Canada and Greenland met those criteria. The Danish Commission for Scientific Research in Greenland and the Danish Meteorological Institute were very interested in having the radar facility located in Greenland. Greenland, at that time, already hosted a large number of geophysical sensors along the west coast and had established a tradition of supporting scientific investigations into ionospheric phenomena. Continuing this tradition, a Memorandum of Understanding was reached between the US National Science Foundation, the US Department of State, SRI International, the Danish Commission for Scientific Research and the Danish Meteorological Institute to establish a research facility in Greenland near the US Air Base of Sondrestrom. (The village had the Danish name of Søndre Strømfjord, and with the closure of Sondrestrom Air Base in 1992 and the transition to Greenland Home Rule, the village is now called by its Greenlandic name of Kangerlussuaq.) The Chatanika Radar was thus moved to Greenland in 1982 and the Sondrestrom Upper Atmospheric Research Facility was established. Operations ceased at Chatanika in March 1982 and began again in Sondrestrom in February 1983 - less than a year later. Figure 4 shows part of the dismantling of the antenna in Chatanika.

During the move process, modifications were made to the radar system. The most visible was the enlargement of the parabolic dish from 27 to $32 \mathrm{~m}$. With a new shaped subreflector (for the existing Cassegrain feed), the net result was an improvement in both efficiency and gain - from 43 to $48 \%$ and from 47 to $49 \mathrm{~dB}$, respectively. 


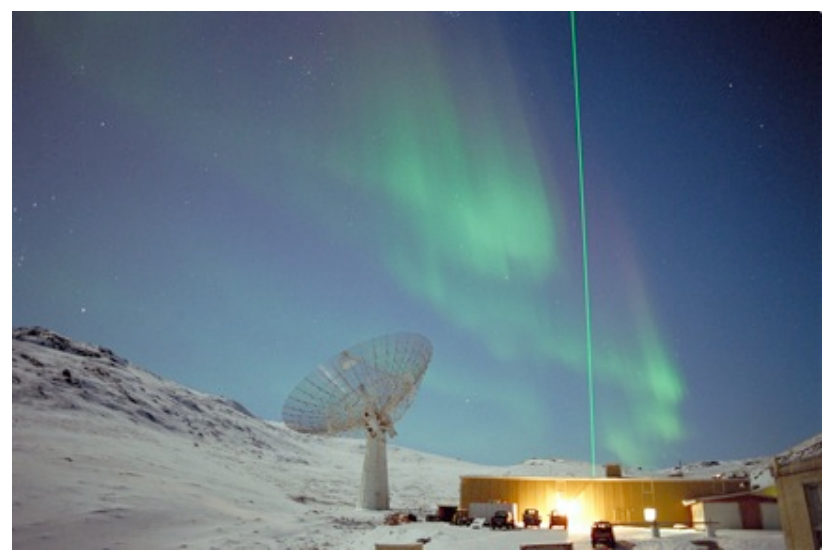

Figure 5. The Sondrestrom Upper Atmospheric Research Facility, showing the $32 \mathrm{~m}$ fully steerable parabolic dish, Rayleigh lidar beam and aurora on a moonlit night. Photo by C. Heinselman.

\section{Becoming a facility}

The scope of the project was expanded to include specific support for other scientific instrumentation - a stable floor for optical benches, multiple roof domes, and the floor space and power capacity to host additional instruments. Thus this became a true scientific research facility which includes the radar as one of its components. The facility has a suite of instruments that contribute to more than just high latitude upper atmospheric studies, including a lidar system, as shown in Fig. 5. The lidar system, with up to four different lasers, has enabled middle atmosphere research, reaching up to $90 \mathrm{~km}$ altitude (Thayer et al., 1997). Tropospheric water vapor measurements are made between 3 and $10 \mathrm{~km}$ altitude (Neely and Thayer, 2010), temperature measurements from 30 to $90 \mathrm{~km}$ altitude, and aerosol measurements throughout the full profile.

The Sondrestrom Radar passes under the average auroral oval at noontime and is within the polar cap at midnight. The first years of measurements revealed as least as many questions as answers. In the winters of 1985 and 1987, sounding rockets were launched from the nearby rocket range and the wealth of data resulted in many scientific publications. Since 1983, scientists from around the world have utilized the measurements made at Sondrestrom and many bring their own unique instruments for that work (Kelly et al., 1995). All research done at the facility is available to the public and is published in the open literature. Since operations began in Greenland, the monthly average of radar operations has increased from 100 to $160 \mathrm{~h}$.

Some of the numerous topical areas well supported by the Sondrestrom Facility include:

$$
\begin{aligned}
& \text { - Storms and substorms } \\
& \text { - Auroral boundaries and particle energetics } \\
& \text { - Electrodynamics and neutral dynamics }
\end{aligned}
$$

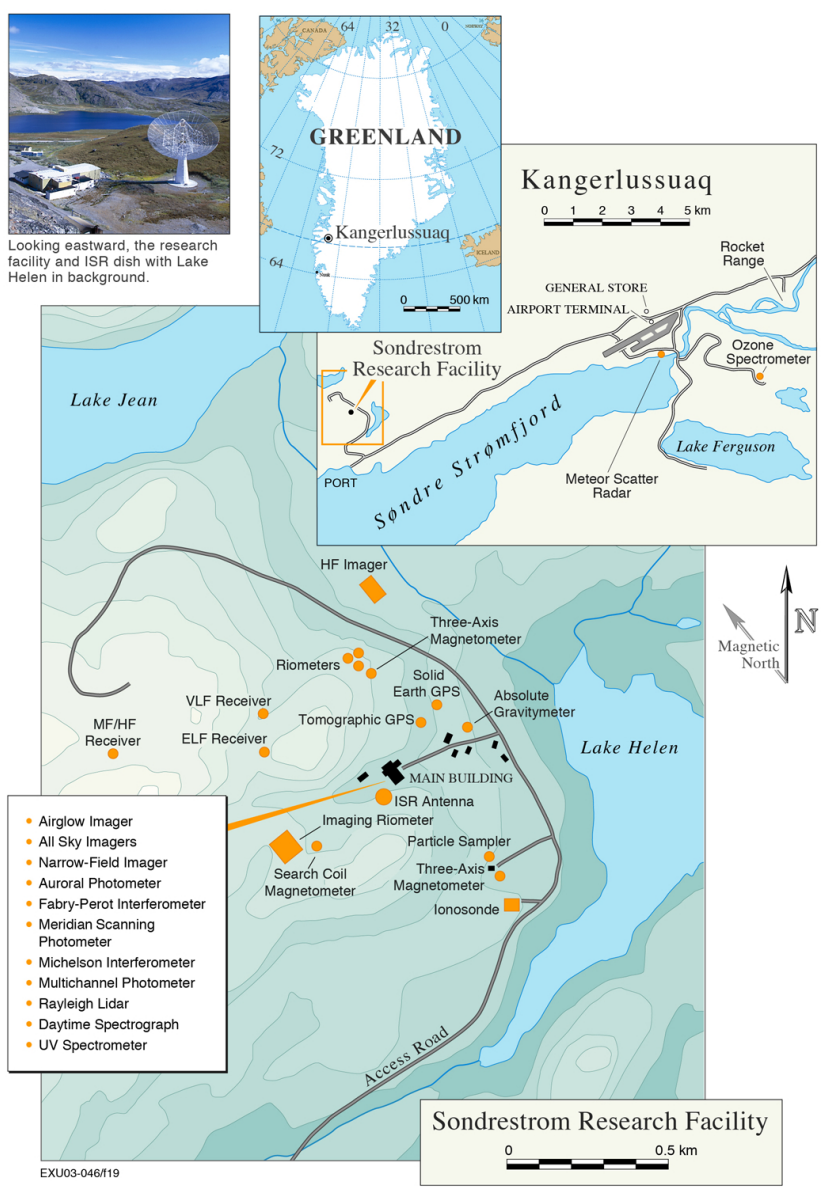

Figure 6. The Sondrestrom Research Facility, located near Kangerlussuaq, just inside the arctic circle on the west coast of Greenland.

- Plasma structures and forms

- Mesosphere/Lower Thermosphere/Ionosphere phenomena

- Middle atmosphere properties

- Ion and neutral thin layers

- Noctilucent cloud studies

A list of peer-reviewed publications using data from Sondrestrom or Chatanika can be found at www.isr.sri.com/pubs. html.

Figure 6 shows the general layout of the site and the locations of many of the upper-atmosphere research instruments it supports. The facility also supports other instruments not involved in upper atmospheric research. Some of the scientific systems are funded by US agencies other than the NSF (National Aeronautics and Space Administration, National Oceanic and Atmospheric Administration, National Center for Atmospheric Research, etc.) and some of them are from institutions in other countries (Denmark, Germany, Luxembourg, currently). In addition to providing shelter, power and 


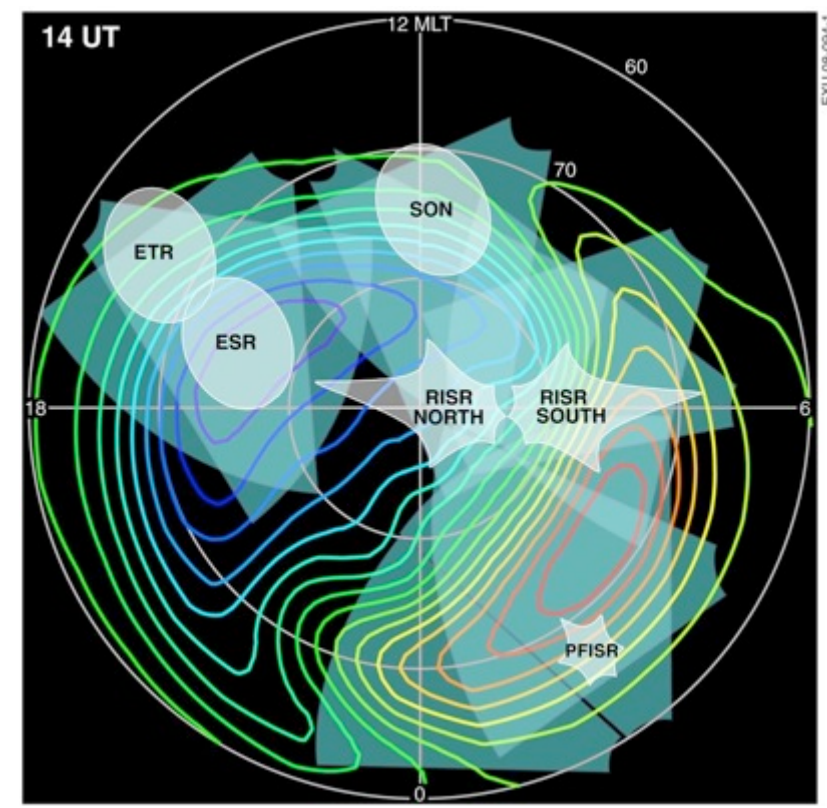

Figure 7. Polar view of the nominal F-region fields of view of the high-latitude ISRs. Included are the fan-shaped fields of view of the SuperDARN radars and color-coded contours of electric fields.

connectivity, the site crew perform routine maintenance, data archival, trouble-shooting, upgrades and repairs as needed, all on a non-interference basis with the radar operations. This suite of collocated instruments has grown over the years from a handful of dark-sky optical instruments to two dozen instruments from 19 different institutions.

Although not a university, SRI strongly encourages and supports student research. Data from the $11 \mathrm{yr}$ facility in Chatanika contributed to 21 Ph.D. dissertations. Presently, data from the Sondrestrom Facility have been used in 64 Ph.D. dissertations with 13 more in progress. The current numbers for publications in refereed journals are 210 and 494 , respectively.

\section{The high-latitude network}

In the 1990s, the EISCAT Scientific Association built a mono-static incoherent scatter radar on the island of Svalbard in the Arctic Ocean (called the EISCAT Svalbard Radar, or ESR, to differentiate it from the EISCAT Mainland tristatic and monostatic radar systems). In recent years, the NSF has funded the deployment of new phased-array ISRs at Poker Flat Research Range, Alaska, and Resolute Bay, Canada. The PFISR (Poker Flat ISR) has been operational since January 2007 and the RISR-N (for Northward-looking Resolute ISR) since April 2009. The RISR-C (Resolute ISR looking southward over mainland Canada), is scheduled to begin operations in the spring of 2013. These new radars, along with the EISCAT Radars and the Sondrestrom Radar, comprise the high-latitude portion of the world wide "network" of incoherent scatter radars. The nominal F-region coverage of these high-latitude ISRs is shown in Fig. 7.

Basic parameters of the Sondrestrom ISR are given here.

$$
\begin{array}{ll}
\text { Geographic Location: } & 66^{\circ} 59.14^{\prime} \mathrm{N} \\
& 50^{\circ} 56.76^{\prime} \mathrm{W} \\
& 196 \mathrm{~m} \text { altitude } \\
\text { Geomagnetic Location: } & 72.35^{\circ} \Lambda(\mathrm{CGM}) \\
& \mathrm{MLT}=\mathrm{UT}-01: 58
\end{array}
$$

Radar Technical Details

$\begin{array}{ll}\text { TX Frequency } & 1290 \text { and } 1290.6 \mathrm{MHz} \\ \text { TX Peak Power } & 3.5 \mathrm{MW} \\ \text { TX Duty Cycle } & <=3 \% \\ \text { Antenna Diameter } & 32 \mathrm{~m} \\ \text { Antenna Gain } & 49 \mathrm{dBi} \\ \text { Antenna Beamwidth } & 0.5^{\circ} \\ \text { Antenna steerability } & >=30^{\circ} \text { elevation } \\ \text { System Noise Temp } & 65 \mathrm{~K} \text { currently }\end{array}$

Basic parameters of the Chatanika ISR are given here.

$\begin{array}{ll}\text { Geographic Location: } & 65^{\circ} 06^{\prime} \mathrm{N} \\ & 147^{\circ} 27^{\prime} \mathrm{W} \\ & 299 \mathrm{~m} \text { altitude } \\ \text { Geomagnetic Location: } & 64.45^{\circ} \Lambda(\mathrm{CGM}) \\ & \mathrm{MLT}=\mathrm{UT}-11: 20\end{array}$

Radar Technical Details

$\begin{array}{ll}\text { TX Frequency } & 1290 \mathrm{MHz} \\ \text { TX Peak Power } & 3.5 \mathrm{MW} \\ \text { TX Duty Cycle } & <=3 \% \\ \text { Antenna Diameter } & 27 \mathrm{~m} \\ \text { Antenna Gain } & 46 \mathrm{dBi} \\ \text { Antenna Beamwidth } & 0.6^{\circ} \\ \text { Antenna steerability } & >=15^{\circ} \text { elevation } \\ \text { System Noise Temp } & \sim 200 \mathrm{~K}\end{array}$

Acknowledgements. The authors thank John D. Kelly and Murray J. Baron for their valuable inputs. The Sondrestrom Facility is supported by the US National Science Foundation under cooperative agreement AGS-0836152.

Edited by: A. Brekke

Reviewed by: B. Watkins and J. C. Foster 


\section{References}

Banks, P. M., Foster, J. C., and Doupnik, J. R.: Chatanika Radar Observations Relating to the Latitudinal and Local Time Variations of Joule Heating, J. Geophys. Res., 86, 6869-6878, 1981.

Baron, M. J.: The Chatanika Radar System, in: Radar Probing of the Auroral Plasma, Proceedings of the EISCAT Summer School, Troms $\varnothing$, Norway, 5-13 June 1975, edited by: Brekke, A., Universitetsforlaget, Troms $\varnothing$-Oslo-Bergen, 103-141, 1977.

Bates, H. F.: Atmospheric Expansion through Joule Heating by Horizontal Electric Fields, Planet. Space Sci., 21, 2073-2088, 1973.

de la Beaujardière, O. and Vondrak, R.: Chatanika Radar Observations of the Electrostatic Potential Distribution of an Auroral Arc, J. Geophys. Res., 87, 797-809, 1982.

Foster, J. C., Doupnik, J. R., and Stiles, G. S.: Large Scale Patterns of Auroral Ionospheric Convection Observed with the Chatanika Radar, J. Geophys. Res., 86, 11357-11371, 1981.

Hunsucker, R. D.: Estimate of the Relative Importance of Joule Heating and the Lorentz Force in Generating Atmospheric Gravity Waves from the Auroral Electrojet, J. Geophys. Res., 82, 4826-4828, 1977.

Hunsucker, R. D., Bates, H. F., and Belon, A. E.: Observations of Simultaneous Auroral D and E Layers with Incoherent-Scatter Radar, Nature Physical Sci., 239, 102-104, 1972.

Kamide, Y. and Vickrey, J. F.: Variability of the Harang Discontinuity as Observed by the Chatanika Radar and the IMS Alaska Magnetometer Chain, Geophys. Res. Lett., 10, 159-162, 1983.

Kelly, J. D. and Wickwar, V. B.: Radar Measurements of HighLatitude Ion Composition Between 140 and $300 \mathrm{~km}$ altitude, J. Geophys. Res., 86, 7617-7626, 1981.
Kelly, J. D., Heinselman, C. J., Vickrey, J. F., and Vondrak, R. R.: The Sondrestrom radar and accompanying ground-based instrumentation, Space Sci. Rev., 71, 797-813, 1995.

Leadabrand, R. L., Baron, M. J., Petriceks, J., and Bates, H. F.: Chatanika, Alaska, Auroral-Zone Incoherent-Scatter Facility, Radio Sci., 7, 747-756, 1972.

Neely, R. R. and Thayer, J. P.: Raman lidar profiling of tropospheric water vapor over Kangerlussuaq, Greenland, J. Atmos. Ocean. Tech., 28, 1141-1148, doi:10.1175/JTECH-D-10-05021.1, 2010.

Robinson, R. M., Tsunoda, R. T., Vickrey, J. F., and Guerin, L.: Sources of F Region Ionization Enhancements in the Nighttime Auroral Zone, J. Geophys. Res., 90, 7533-7546, 1985.

Robinson, R. M., Vondrak, R. R., Miller, K., Dabbs, T., and Hardy, D.: On Calculating Ionospheric Conductances from the Flux and Energy of Precipitating Electrons, J. Geophys. Res., 92, 25652569, 1987.

Thayer, J. P., Nielsen, N. B., Warren, R. E., Heinselman, C. J., and Sohn, J.: Rayleigh lidar system for middle atmosphere research in the arctic, Opt. Eng., 36, 2045-2061, 1997.

Watkins, B. J. and Belon, A. E.: Incoherent-Scatter Radar Measurements of Electron Density and Ion Velocity During an Isolated Substorm, J. Atmos. Terr. Phys., 40, 559-564, 1978.

Wickwar, V. B., Meriwether, J. W., Hays, P. B., and Nagy, A. F.: The Meridional Thermospheric Neutral Wind Measured by Radar and Optical Techniques in the Auroral Region, J. Geophys. Res., 89, 10987-10998, 1984. 